\title{
9
}

\section{A new European Union}

A state without the means of some change is without the means of its own conservation. (Edmund Burke) ${ }^{1}$

\section{Summary}

A series of EU summits - Amsterdam in I997, Berlin and Helsinki in 1999 and Nice in 2000 - focused on the need for inner reform of the institution against the prospect of future enlargement and new competences. The general tendency was for increased intergovernmentalism, that is, more power in the hands of the EU's Council of Ministers and greater influence for the European Parliament.

The Helsinki Summit decided to accept candidacies of thirteen countries (including Turkey) and to start negotiations with twelve (all but Turkey) on an equal basis, with 2004 as a possible date for joining by the first in line. It was also decided to establish, by 2003 , a 60,000-strong Rapid Reaction Force capable of performing peacemaking or peacekeeping operations autonomously of NATO.

The Nice Summit confirmed and codified the trend towards intergovernmental dominance in the EU, especially by the larger member states. This may have been one reason why the Nice Treaty was rejected by the Irish in a referendum in June 200I, an outcome that jeopardised the treaty's planned entry into force in preparation of enlargement.

Various leading politicians in EU member states in 2000 and $200 \mathrm{I}$ offered their visions of the necessary future structure of the institution ranging from the federal to the (continued) intergovernmental to the interparliamentary to the (continued) bureaucratic. With EU funds scarce, efficiency suffering, democracy found lacking, the physical introduction of the euro imminent and major enlargement around the corner, the debate had come none too soon.

An EU Convention on the Future of Europe was consequently convened in 2002 with a mandate to make proposals to governments for a 
new EU constitution in 2003 . This would be necessary also to prepare for the 'big bang' enlargement decided at a summit in Copenhagen in December 2002, where it was agreed to invite ten candidate countries to join in 2004: Cyprus, the Czech Republic, Estonia, Hungary, Latvia, Lithuania, Malta, Poland, Slovakia and Slovenia. Negotiations would continue with Bulgaria and Romania, with a possible date of accession set for 2007 . It was also decided that an attempt would be made in 2004 to set a date for the start of membership negotiations with Turkey. Thorny questions remained, however, such as how to reform the Common Agricultural Policy and EU finances overall in order to accommodate the many new and less wealthy member states.

\section{The Amsterdam Summit, June 1997}

The European Union is characterised, strangely enough, by both inertia and capacity for change. Some policies - such as those on agriculture, fisheries and regional support - bitterly resist renewal, while others - such as on enlargement, monetary unification and security - show remarkable adaptability in the face of new impulses. It is worth following how EU thinking has evolved over the 1997-2003 period, as manifested in the decisions taken at six summits: Amsterdam in 1997, Berlin and Helsinki in 1999, Nice in 2000, Laeken (Brussels) in 200I and Copenhagen in 2002 .

In Amsterdam, in June I997, EU leaders crowned the efforts of an Intergovernmental Conference (IGC) started fifteen months earlier, by adopting the Amsterdam Treaty. The treaty foresaw EU membership negotiations to start in 1998 with six 'first wave' applicant countries: Cyprus, the Czech Republic, Estonia, Hungary, Poland and Slovenia. Five other countries would later be invited to start negotiations for a 'second wave' enlargement: Bulgaria, Latvia, Lithuania, Romania and Slovakia. 'First wave' accessions were considered likely around 2004 at the earliest.

In the Amsterdam Treaty environment protection was given a higher profile (at Scandinavian insistence), in that individual member states would be able to introduce stricter standards than those valid for the rest of the EU. Majority voting in the Council of Ministers was extended (at the cost of the unanimity rule). ${ }^{2}$ And the position of the European Parliament was strengthened, as was the say of national parliaments. ${ }^{3}$

However, other tasks remained largely unresolved. One was EU institutional reform, seen as a prerequisite for enlargement, since with the present machinery the institution would risk paralysis with more 
than, say, twenty members. Here it was decided to continue negotiations nearer to the time of actual enlargement, presumably in the hope that urgency would help concentrate minds. (It was subsequently agreed that an overhaul would be undertaken as from twenty member states, i.e. between the 'first' and the 'second' wave.) All that could be agreed on in Amsterdam was a strengthening of the position of the Commission's President and to have the number of Commissioners remain at a maximum of twenty. ${ }^{4}$ Furthermore, Amsterdam saw a battle between the smaller and the bigger EU member states, in particular as regards the 'one-country-one-vote' principle in the Council of Ministers. The bigger had hoped for a weighted voting system based on population, but the smaller put up successful resistance.

The Common Foreign and Security Policy vaguely set out in the Maastricht Treaty was left nearly in the same embryonic stage in which it had found itself previously. The Amsterdam Treaty also saw procedural simplifications in the complicated decision-making process, the creation of a joint planning body, and a raising of the status of the Secretary General of the EU Council of Ministers.

One innovation of the Amsterdam Treaty was the introduction of 'flexibility' in the future construction of the Union; that is, the possibility for a qualified majority of countries (7I per cent of the weighted votes) to engage in deeper co-operation in various fields without being stopped by the others. Flexibility, it was felt, would become more and more necessary as the EU was enlarged to include more and more heterogeneous countries from the political, economic and cultural point of view. It would therefore become increasingly difficult to 'deepen' the Union in ways that could be supported and implemented by each and every one. The 'EU-isation' of policies on asylum, immigration and visas, as well as the Schengen Agreement on uncontrolled internal EU borders, was seen as already illustrating this, as they contained many exceptions for different countries. The challenge for the EU would be to ensure that flexibility did not lead to uninhibited 'Europe à la carte' policies by its member states and to any further weakening of its cohesion. ${ }^{5}$

The relatively meagre results of Amsterdam reflected the resistance waged by intergovernmentalism against integrationism. That is, the member states, through their governments (and to some extent parliaments) fought for the powers of the Council of Ministers to be defended against the increased powers of the Commission. In this sense Amsterdam meant a development of the EU towards a more classical international set-up such as the Strasbourg-based Council of Europe. ${ }^{6}$ 


\section{The Berlin Summit, March 1999}

The emphasis in Amsterdam in 1997 had been on the principle of EU enlargement and the inner reforms necessitated by it. In Berlin in March I 999 it shifted to budgetary reform to finance the EU's various programmes during the 2000-6 period, and to the question of who should pay how much. An Agenda 2000 for an overhaul of the EU's financial structure, the CAP and regional support was agreed, though in a much toned-down form compared to what the Commission had originally proposed.

Germany had not been able to reduce significantly its role as the biggest net contributor to the EU budget (about $€_{9.3}$ billion more in contribution than in receipts in 2000 , or 60 per cent of EU transfers from richer to poorer members), but as host it had a strong interest in avoiding a breakdown in the negotiations. Other major net payers - the Netherlands, Sweden, Austria - were not much relieved either, nor were net receivers much disturbed. Spain, in the last night of talks, managed to squeeze out an extra $€_{3}$ billion from the EU's structural and regional funds, which in total would amount to over $€_{200}$ billion for the six-year period. (In a reform of how the funds should be distributed, the summit decided that more should go to the very poorest regions in the EU, rather than to all except the richest, as had previously been the case.)

The United Kingdom was able to keep most of the special rebate it had obtained in the Thatcher years (due to the particular situation of its agriculture). France obtained most of what it wanted, in particular smaller reductions than foreseen for its own and other countries' farmers. Yearly CAP expenditure was to be kept at around $€_{4} \circ$ billion, less than half of the equally 'frozen' total EU expenditure of about $€_{9 \circ}$ billion (representing a maximum of I.27 per cent of EU GDP). In all, the Berlin Summit was a grab for money from all sides, a struggle to keep privileges, however outmoded, or of redressing perceived injustices.

The agreements reached in Berlin, like those in Amsterdam in I997, appeared meagre, especially when measured against the original proposals in the Commission's Agenda 2000. Consumers and tax-payers could have gained more if CAP prices had been more free-market-oriented. More could have been done with less EU money if the structural policy had been more specifically directed at the poorest regions. Greater understanding could have been shown with regard to the big net payers' positions.

However, a basis was thought to have been laid for sounder EU finances in the future, in that the CAP and overall expenditure was 
stabilised up to the year 2006. EU enlargement seemed more feasible from the financial point of view. The summit also showed a realisation that 'bribe money' would not be available to the same extent as in the past in order to smooth over disagreements between member states. The net payers promised to be less generous in future and the net receivers were warned they might have to adapt to a 'leaner and meaner' EU.

\section{The Helsinki Summit, December 1999}

At the December 1999 EU summit in Helsinki it was decided to bring the number of EU candidate countries from the six agreed at Amsterdam (Cyprus, the Czech Republic, Estonia, Hungary, Slovenia and Poland) to thirteen. Negotiations would start in 2000 with Bulgaria, Latvia, Lithuania, Malta, Romania and Slovakia. In addition, and more controversially, Turkey was accepted as a candidate, although no date for the start of negotiations for membership was fixed. ${ }^{7}$

The talks with all the twelve candidates (i.e. minus Turkey) would take place concurrently, along the lines of the so-called 'regatta model': all were to depart from the same starting line as far as their actual or expected adherence to each and every one of thirty-one 'chapters' in the acquis communautaire. The progress of each country would be judged according to the same criteria. (To the various economic requirements should be added the so-called 'Copenhagen criteria' agreed within the EU earlier, calling on EU candidates to maintain democracy, the rule of law, respect of human rights and the protection of minorities.) It was hoped that, in this way, improvements reached by especially the original six candidates would not delay their accession, while new candidates would have a chance to accelerate their reform process and catch up with the rest.

Some Balkan countries were excluded from candidate status, such as Bosnia-Herzegovina, Croatia, the 'former Yugoslav Republic of Macedonia' and, for obvious political reasons at the time, the Federal Republic of Yugoslavia. At least the first three could, however, be said to have been covered by the Stability Pact for South-Eastern Europe, ${ }^{8}$ while awaiting the day when their economic (and political) maturity might be such as to qualify them for candidate status.

Meanwhile, the EU was to reform itself in order to be ready in its turn to receive new members. An Intergovernmental Conference (IGC) would be set up in 2000 and given until 2002 to finish its work (i.e. one or two years before the first expected enlargement). The main task was to make sure that a much larger EU could work efficiently and reach decisions. 
Among the issues discussed were the size and composition of the Commission; the number of votes per country in the Council of Ministers and a possible wider use of qualified majority voting in that body; and prospects for a further enlarged role of the European Parliament. ${ }^{9}$

Turkey's inclusion among the candidate countries in the eleventh hour of the Helsinki Summit gave rise to considerable debate among commentators. Some were asking where the EU was heading in preparing to accept a predominantly Muslim country or where indeed Europe's political, cultural and geographic borders could now be said to lie. Others, however, pointed to Turkey's major, and growing, geopolitical importance and the need to bind it more closely to Europe.

European co-operation in the political, security and defence fields took a major step forward, at least on paper, when the Helsinki Summit also agreed to create, by 2003, a 60,000-strong, air and navy supported Rapid Reaction Force (RRF) ready to go into action within sixty days. ${ }^{\text {IO }}$ The Rapid Reaction Force, meant to form part of the EU's European Security and Defence Policy (ESDP), was to be used only in extreme cases of conflicts in Europe or its vicinity. Emphasis would be laid on the so-called 'Petersberg tasks' of peacekeeping or peacemaking. These also included conflict identification and prevention, including emergency assistance, police training, the building of a civil society and even trade policies for economic stability. The tasks of the Western European Union, which up to then had served as the main expression of European security defence policies, would for all practical purposes be taken over by the EU. ${ }^{\text {II }}$

The UK, France and Germany would together provide around 40,000 troops, with all the other EU members making up the remaining 20,000 - all from within a pool of 200,000 men for rotation purposes. Troops from EU countries that were members of NATO would be 'doublehatted', that is available for either EU or NATO duties as the situation might require. (One can therefore not talk about any 'European army' in its own right, only about the use of national armed forces, whether from NATO or non-NATO EU countries.) They would be used for more limited roles of crisis management when NATO as a whole was not involved.)

It was also agreed that EU military activity would come under its Council of Ministers, with no role for either the Commission or the European Parliament. As if to underline this fact, the policy was to be managed by about a hundred military staff at EU headquarters in Brussels, under the EU's High Representative for Security and Foreign Policy, who was also the Secretary General of the Council of Ministers. ${ }^{\text {I2 }}$ 
The Helsinki decision to create a Rapid Reaction Force built on the British-French St Malo Declaration of 1998 and had to be seen against the background of the relatively undistinguished military performance by the European members of NATO during the Kosovo conflict. For France, the new project represented a means to assert increased European independence and power. For a United Kingdom outside the Economic and Monetary Union, it provided a chance to continue to play a leading role in European affairs. With Germany, perhaps surprisingly, so enthusiastically behind the new initiative, it became a fait accompli for many of the smaller, more hesitant and sometimes neutral EU member states.

The US (and Canadian) reaction to the European Security and Defence Policy was ambivalent, reflecting the age-old US uncertainty as to whether its security, and that of Europe, was better assured by exerting a dominating influence over it or by withdrawing from it. US worries included: a possible 'decoupling' of North American and European security; discrimination against the US, or against non-EU NATO members Iceland, Norway and Turkey and these countries' exposure to new risks, especially since they might have to come to the rescue of EU members also belonging to NATO, under the latter's collective defensive obligation; a lacking European will to increase defence capabilities to the level necessary for separate action; and duplication of effort, as the new EU structures would work parallel to already existing NATO ones set up to cater for European-led operations (after a Defense Capability Initiative was adopted at NATO's fifty-year anniversary summit in Washington in 1999 to improve the strength of European military forces).

Further transatlantic worries concerned the risk of reduced interoperability' between NATO and EU defences; possible clashes resulting from further NATO and EU enlargement (now with defence commitments) such as in the case of the Baltic States; possible confusion in future crises, such as over who should intervene - NATO or the EU (or both); and the risk that the EU might 'rush in where angels fear to tread' in order to prove its untested worth.

Complicating the situation was the fact that France, although a NATO member, was not part of NATO's integrated military structure. Could EU military planning take place apart from NATO when the EU would for a long time need NATO resources? Would the US (and the Canadians) remonstrate by not sharing intelligence or by reducing their commitment to NATO.

Above all, would the EU be able to afford the establishment of a European Security and Defence Policy, given not only the growing gap 
between US military technology and that within the EU, but also shrinking defence budgets in most EU countries? ${ }^{\mathrm{I} 3}$ It was estimated that the already under-financed military forces of the UK, France and Germany would have to increase by half in the next ten years to meet the ESDP commitments - a politically delicate task before electorates that could see no real security threat on the horizon. ${ }^{\text {I4 }}$

On the other hand, the project was seen as having the potential to encourage transnational mergers in the European defence establishment, permitting it to recuperate some of the US lead in weapons technology. Furthermore, stronger economic growth could permit defence budgets to start growing again, especially since defence spending could create new employment. ${ }^{15}$ The bigger countries - especially the UK, France and Germany - seemed to feel that a single security policy was a natural next step after the Internal Market and the single currency. Such a policy would be particularly needed if the United States should ever wish to 'decouple' itself from Europe. At the same time it could provoke such a 'decoupling'. This was, in brief, the Europeans' dilemma.

It remained to be seen how great an impact on NATO the European Security and Defence Policy would have and whether the Rapid Reaction Force would actually be deployed independently of NATO. A number of factors made this less likely. First, it would be difficult and slow for the EU to reach agreement on actually deploying the RRF, since the member states - three of which (Austria, Ireland and Sweden) considered themselves unable to join military alliances - were all democracies, eager, under popular pressure, to avoid foreign policy initiatives, especially if these had a military component. EU members would likely interpret threats differently. Only when all agreed on a threat scenario and the necessary measures to combat it would it be possible to deploy troops (a hope punctured by the Iraq crisis in 2003).

Second, major EU players such as France, Germany and the UK had different interests in creating the ESDP, a circumstance that was seen as likely to hamper its effectiveness. France wanted it eventually to lead to full security independence from the US and NATO. Germany wanted greater EU integration, a development that would require greater defence autonomy. However, Germany also wanted a lasting US-NATO presence to prevent any emerging national rivalries within the EU. Finally, the UK needed to be shown to be involved in Europe at a time when it was outside the Economic and Monetary Union.

EU foreign policy in the early 2000 s often lacked coherence, as it often criticised and sought to be distinct from US positions without presenting clear alternatives. The latter were all the more difficult to identify as the 
various EU countries, each with its own foreign policy establishment and objectives, stood far apart on many issues. One example was a sudden EU diplomatic opening to North Korea in 200I, unaccompanied, however, by any tangible initiative to solve that country's conflict with South Korea. This was followed by a near-absent EU policy on North Korea as the showdown over that country's nuclear armament came to a head in 2003.

A second example was the serious split over Iraq in 2003 between those - such as the UK, Spain and Italy - who stood by the US in seeking Saddam Hussein's ouster, if necessary through an invasion; and those countries, led by France, Germany and Belgium, who advised against any invasion until a UN Security Council authorising it could be secured. As the US-British led invasion took place, the EU's attempts to forge a common European Security and Defence Policy suffered a serious blow, since nobody could guarantee that perceptions of outside threats and the action required to counter them would be any less diverse than they had been over Iraq.

However, EU successes in the foreign policy field were also scored, such as in the 'former Yugoslav Republic of Macedonia' in 200I, where a peace agreement was reached between Slavs and ethnic Albanians, thanks to concerted EU (and US) action, and where the EU took over peacekeeping duties in 2003.

\section{The Nice Summit, December 2000}

During three days (and nights) in December 2000, European Union leaders laboured to make the Union better fit to receive up to twelve (thirteen if Turkey was included) new members. ${ }^{16}$ The internal reform would have to include especially the decision-making Council of Ministers but also the Commission. The general drift was towards even more intergovernmentalism, that is, the joint rule by national governments in the Council of Ministers, fortifying the thesis made by some observers that the EU, far from heralding the end of the nation-state, in fact had come to its rescue and had perhaps been invented by EU member states to preserve it. ${ }^{17}$

In the end, in a confusing night session on the third day of negotiations, when nobody quite knew how the arithmetic would work (indeed it had to be fine-tuned in the weeks to follow), the 'big four' (France, Germany, the UK and Italy) received 29 votes each, Spain 27, the Netherlands I3, Greece, Belgium and Portugal I2 each, Sweden and Austria Io each, Denmark, Finland and Ireland 7 each and Luxembourg 4. It was agreed that 88 votes out of the total 227 would be enough to block decisions in a majority-decision domain of activity. ${ }^{28}$ 
Nice also signified a drift within the Council of Ministers towards greater dominance by the bigger countries - France, Germany, the UK, Italy and Spain - vis-à-vis the smaller ones, based on size of population. (This was natural enough, considering the drift toward intergovernmentalism. With more power for the Council of Ministers, greater care had to be taken to ensure that this power reflected demographic realities.)

A further sign of big-country domination was the request to limit the right of veto to fewer areas in favour of majority decisions. (Veto right is above all a means of defence for the smaller countries to resist decisions going against them.) In the end, the new areas where majority decisions would replace the unanimity rule were fewer than had been anticipated, as different countries, not least the big ones, exercised their veto rights to prevent change: the British against any extension to fiscal and social matters, the French and the Finns on culture, the Germans on immigration and asylum, the Danes on labour market issues and so on. In the end, majority voting was extended to thirty-five new areas, including regional funding and services (but not cultural services such as television and film).

Nice also agreed that, as from 2005 , the Commission would keep its current size of twenty Commissioners regardless of any further EU enlargement. The five countries with currently two Commissioners (France, Germany, the UK, Italy and Spain) would content themselves with only one, leaving five seats to any new members. By the time the EU had reached twenty-seven member states, the number of Commissioners was to be reduced from twenty to a lower, still undecided, number. The concession by the big countries could be better understood when seen against the background of the reduced power of the Commission. Why bother about representation in a body that presumably would have less influence? Furthermore, since Commissioners were at any rate supposed to be neutral and work for the EU - not for their countries of origin and were normally forced by inside and outside pressures to do so anyway, the fact of giving up a seat might not amount to much.

One achievement in Nice was to prepare the ground for 'flexible integration' in various fields, such as social policies or taxation, among a stipulated minimum of eight member states, along the lines of the Economic and Monetary Union. Even though this potentially prepared the ground for 'several EUs within the EU', it also reflected the need for a more heterogeneous membership to integrate at different speeds. It remained to be seen which countries would then team up on what subjects, in order to proceed in advance of the others. Finally, Nice produced a Charter of Fundamental Rights, which did not have treaty value but which some people hoped would form part of a future EU constitution. 
Even though the immediate reactions from member states - especially the smaller - after Nice were sceptical or disappointed (also at perceived French bullying during the negotiations), it remained to be seen how the agreement would work in practice. Would power move even more in the direction of the member governments as widely foreseen, and away from the Commission and the European Parliament (whose powers had, after all, been increased in the Amsterdam Treaty)? Would the Commission and the Parliament 'gang up' against the Council of Ministers to compensate for loss of influence, and how effective would such an alliance be? Would the (moderately) increased number of areas where majority voting was to replace the unanimity rule make the EU less prone to decision-making paralysis and instead make it more effective? Would the EU's new 'flexibility' clause, which permitted groups of countries to go further than others, be a source of division and confusion, or would it resolve the old 'deepening-versus-widening' dilemma of the institution? Would the EU be perceived by EU citizens as being closer to them, as 'national' interests were defended by 'their' government in the Council of Ministers? Or would it be perceived as being further away from them as the role of the European Parliament - the 'voice of the people' - was less prominent and as the Council of Ministers decided by a majority vote in more areas?

There was genuine concern about the EU's 'distance from the people' as the institution embarked on matters more and more central to the everyday life of citizens, such as the management of the euro and the migratory pressure to be expected from the next stages of enlargement. Nor was there any agreement upon the 'finality' of the EU, nor the road there. The risk was one of growing resistance - and a resulting rise of populist, nationalist parties - against continued EU integration as it reached nationally 'vital' areas. Alternatively, there could be a growing feeling of 'togetherness', as various acts of bringing the European Union together took place, as had indeed been the case over much of the Union's history.

In a first setback to the Nice Treaty, Irish voters in a referendum in June $200 \mathrm{I}$ rejected it by a margin of 54 per cent to 46 per cent (with only about a third participating in the vote). Together with the Danish referendum 'no' in 2000 to the euro, the Irish referendum was a renewed reminder to the EU that something was amiss in the unification process.

Irish voters had above all been uneasy that Nice was relegating smaller powers in the EU to a secondary position, through loss of voting power in the Council of Ministers and the increased use of majority decisions in that body. Furthermore, the Irish objected to what they saw as their 
country's forced abandonment of its neutrality through the new military responsibilities of the EU. The Irish vote pointed to a growing estrangement on the part of EU citizens vis-à-vis the EU, which was seen as increasingly opaque and secretive and distant from EU burghers and their concerns. By contrast, the vote did not seem to reflect any popular sentiment against EU enlargement, even though that was highlighted in the international reaction within the EU, where many argued that enlargement and the Nice Treaty in general would have to go ahead regardless.

The other EU countries refused any renegotiation of Nice with the Irish (as had been done with the Danes on Maastricht) and still expected ratification by all the Fifteen (i.e. including Ireland) to permit the treaty's entry into force in 2003 . However, the treaty's requirement that it be ratified by all countries, coupled with the uncertain prospect of a 'yes' in another Irish referendum to be held in October 2002, would have forced the EU into unchartered legal territory, had it gone ahead as if nothing had happened.

It was fortunate for the EU, therefore, that a second referendum in October 2002 approved the Nice Treaty by a comfortable margin, permitting it to enter into force in February 2003. Some critics wondered what referenda on EU treaties were worth, if negative results were not tolerated and new ones had to be held until approval was won. Others asked why referenda were admitted at all and recommended that ratification through the national parliaments should suffice in all member states.

\section{New visions for the European Union}

In the spring and summer of 2000 the debate on the future of Europe and especially the EU was given new impetus with a speech by German Prime Minister Joschka Fischer. ${ }^{19}$ Fischer, in May 2000, called for an EU federation with a constitution, a directly-elected President, the Commission as a form of government, and a bicameral parliament with a Senate representing the member states and the European Parliament representing the EU population as a whole. The locomotive behind such a development should be a 'core Europe', a 'centre of gravity' - of Germany and France and any other willing country. It was time, he said, at a later press conference, to finish with the 'Monnet method' of opaque and technocratic decision making behind closed doors that had started with the Schuman Plan in 1950 (as devised by Jean Monnet) and the 1958 European Coal and Steel Community and had ended with the Maastricht Treaty. ${ }^{20}$ 
The French reply was courteous but reserved. President Jacques Chirac, a few days later, approved of the 'core Europe' idea and the need for stronger French-German integration, but never once used the word 'federal'. Instead he emphasised the enduring importance of the nationstates, whose 'natural convergence', he maintained, constituted Europe's real strength. ${ }^{2 \mathrm{I}}$ The French Minister of the Interior, Jean-Pierre Chevènement, went so far as angrily to react against a 'Germany still dreaming of the Holy Roman Empire of the German Nation', adding that it had 'not yet recovered from the derailment caused to its history by national socialism'. ${ }^{22}$

The reactions from Italy and Spain were subdued, and that of the United Kingdom as reserved as could be expected from a Blair government wary of even submitting the EMU issue to a referendum. The small nations seemed to be against the Fischer proposal, mainly because they feared the increased dominance in the EU that it presaged for the big EU countries.

Responding to Fischer's call for an EU federation of nation-states and Chirac's urge for a limited number of countries to pursue closer integration if they so wished, British Prime Minister Tony Blair in a speech in Warsaw in October 2000 said that EU enlargement should be the priority, lest Europe again be split in two halves, and that national governments should play the leading role in the running of the EU as the 'basis of democratic legitimacy'. He also called for a second chamber of the European Parliament comprised of members of national parliaments, to ensure that the Union would stick to common EU matters and not interfere in national policy areas.

Blair also suggested an EU 'troika presidency' to shorten the time between national EU presidencies for member states (intervals of seven years with fifteen members and thirteen years with twenty-five). Blair did not wish to see an EU constitution established, but rather an 'EU Charter of Competencies' of a non-legislative nature, clearly spelling out EU and national prerogatives. He also proposed a second EU legislature, supplementing the European Parliament and consisting of members of national parliaments. Its task would be to supervise the respect of the 'Competencies Charter'. (The role of the European Commission would be correspondingly reduced.)

The former French President Valéry Giscard d'Estaing and the former German Chancellor Helmut Schmidt made their contribution to the debate by announcing a preference for an EU restricted to the present Fifteen plus Hungary, Poland and the Czech Republic. The other candidates should, they said, belong to a new, separate organisation to be 
established for economic and trade co-operation, with only a minimum of political integration.

In April 200I, the President of Germany, Johannes Rau, outlined his vision of the future EU before the European Parliament in Strasbourg. His main concern was the preservation of Europe's diversity and he therefore proposed a federation of EU member states based on a federal constitution (similar to Blair's ideas). The constitution would have three parts: the Charter of Fundamental Rights declared at the Nice Summit in December 2000; a definition of EU and member-state rights; and a structure for the federation consisting of a two-chamber parliament where the EU Council of Ministers (not the national parliaments as in Blair's proposal) would form a second chamber supplementing the European Parliament.

Furthermore, to remedy the European Commission's 'democratic deficit', Rau proposed that the Commission's President should be elected directly by the EU population or by the two chambers of parliament. However, the European Commission would keep the right to propose EU legislation, since in his view the limits of intergovernmental initiatives had been reached.

Following the Fischer and Rau proposals, and as if to underline Germany's leading role in the new EU, German Chancellor Gerhard Schröder in April 200I presented his ideas for the European Union's future. The European Commission would be the EU's government. The European Parliament would gain critical new powers by having 'complete budget authority', while the present power broker, the Council of Ministers, would become the EU's second chamber of parliament, supplementing the European Parliament, and thereby filling the EU's 'democratic deficit', which Schröder saw as lying in the Council's secretive deliberations. By contrast, competence over issues like the EU regional and structural policy would be returned to the nation-states.

In May 200I, Romano Prodi, President of the European Commission, predictably called for much more power in the hands of the Commission, which should be turned into a 'European government' for economic policy, foreign policy and defence (with the EU's High Representative for Security and Foreign Policy joining it as a member). It would serve as the political counterweight to the European Central Bank for management of the euro. It would also administer a 'European tax', replacing the present budgetary system of the EU. In other words, an EU run by a bureaucratic body without any direct democratic accountability.

Also in May 200I, French Prime Minister Lionel Jospin added his 'vision', which was very reminiscent of that of Prodi. Its emphasis was 
on the need for continued intergovernmental rule over the EU through the Council of Ministers; more harmonised social and labour legislation; universal access to supplementary schooling in another EU country; an 'economic government' to supervise the European Central Bank; more subsidies for European culture; a transnational, multilingual European television network; more European agencies such as an EU police force and a European prosecutor; a harmonised European corporate tax level; and more restrictions on tax advantages in different EU countries and on competition in international trade.

Jospin also called for the election of the President of the European Commission by the European Parliament (and not, as at present, by member states with the approval of the European Parliament) and for the right of the Council of Ministers (on the advice of the Commission or of member states) to dissolve the European Parliament.

In sum, the 'visions' ranged from the federal-parliamentary (Fischer, Rau and Schröder) to the intergovernmental (Chirac and Blair) to the bureaucratic-intergovernmental (Prodi and Jospin). The discussion was refreshing, since it showed how open the EU's future still was. It was not too dissimilar from what took place when the American constitution was drawn up in Philadelphia in 1787 , with the difference that in the EU's case years went by, not weeks. The big question was, however, whether the EU intergovernmental conference convened for 2004 to review EU institutional reform would have a constitutional mandate (as the Germans, Dutch and others preferred) or not (as was the British wish in particular).

Would Europe be able to manage these challenges? The writer Michael Prowse saw the '2 Ist century as belonging to Europe - to that unique and underrated political organisation called the European Union'. The twenty-first century would be Europe's, he argued,

because it will offer the world the most satisfying overall combination of individual liberty, economic opportunity and social inclusion. It will offer the individual more freedom than intolerant Asia. And the value of this freedom will be enhanced by a sense of community and a commitment to social welfare that is largely missing in atomistic America. That will make Europe an unbeatable bargain. ${ }^{23}$

A contrasting view was put forward by Lord Howell of Guildford, at the time the chief Tory spokesman for foreign affairs in the House of Lords. Howell argued that what Europe needed might in fact be less integration, not more. He wrote:

The merging of nation states, like corporations, and the building of bigger and bigger blocks and institutions to preside over them can sometimes mean 
advance. But it can also mean heavy centralisation and stagnation. In the modern milieu of webs and electronic networks, ideas of block-building and centralisation can seem particularly inappropriate ... and it may prove easier to bind people and societies together by not pushing them together.

Howell went on to call on the builders of modern Europe to muster the courage to show that there are different models for European advance, and that closer integration is not necessarily the best one ... There may not even be a clearly definable goal for modern Europe. It may turn out to be more of a continuous process of bargaining and adjustment, managed by a reformed and a sharply downsized Commission. ${ }^{24}$

Not all of Howell's compatriots would have agreed. The British political thinker Larry Siedentop, for example, urgently wanted the EU to adopt a federal constitution, not so that it would become more centralised but, to the contrary, so that clear limits could be set against any encroachment by Brussels into the proper domains of member states or regions. Only in this way could real meaning be given to the Maastricht concept of 'subsidiarity'.

Siedentop saw three current national approaches to EU integration. The 'French' approach - born out of France's traditional centralism under a grande école, still essentially Jacobinic, elite - would try to do the same with the EU, thereby making it centralist, bureaucratic and secretive. The second was the 'British' approach, which was to avoid excessive centralisation on an ad hoc basis, but without any grand strategy or theory for doing so. This method, Siedentop feared, was bound to fail in the face of the centralist onslaught brought about by the 'French' approach.

The third approach, and the one favoured by him, was the 'German', building on the positive German experience with a federal constitution established after World War II and largely inspired by that of the United States. By overly fearing the 'F-word' (federalism), Siedentop concluded, those against excessive Brussels power were in fact undermining their own cause. Only a constitution setting out the strict limits of central power could lastingly protect the prerogatives of member states and democracy itself. ${ }^{25}$

\section{The 2002 Convention on the Future of Europe}

The EU summit in Nice in 2000 had concentrated on ways to enable the institution's decision-making machinery, above all within the intergovernmental Council of Ministers, to cope with the arrival of up to twelve 
new members from the mid-200os onwards. This was clearly not sufficient to prepare the EU as a whole - that is, its other institutions and its policies - for such a development. The 'vision' debate on the EU's future (described earlier) therefore started shortly after Nice and led to the establishment, at the EU summit in Laeken (Brussels) in December 200I, of an EU Convention on the Future of Europe.

The convention, presided by former French President Valéry Giscard d'Estaing, started its work in February 2002. It brought together around a hundred delegates and representatives of national governments of EU member states and candidate countries, the European Parliament, national parliaments and the European Commission around a mandate of proposing necessary changes to EU treaties (or a new treaty), to ensure that the institution could function democratically, efficiently and close to EU citizens in decades to come. ${ }^{26}$ The proposals of the convention would be ready by 2003 , for ultimate adoption (after likely modification at an intergovernmental conference) at an EU summit. The new treaty would be in place, it was hoped, in time for the next EU enlargement in 2004.

Valéry Giscard d'Estaing in his speech opening the convention in February 2002 said that it should ask itself what the Europeans in an enlarged EU wanted Europe to be, now that the continent had overcome its divisions and found peace. The world as a whole, he continued, needed a strong, united and peaceful Europe that stood by its international commitments and promoted tolerance and democracy. The convention should shape its recommendations according to all these expectations, in defining the EU's institutional architecture, competences, inner functioning and democratic legitimacy. Above all, he concluded, it would have to arrive at a consensus on a single document and not let itself break up into factions.

Pat Cox, the Irish President of the European Parliament, in his speech on the same occasion emphasised the need to make the EU more democratic and more parliamentary, while Romano Prodi, the President of the European Commission, spoke of the development of the EU as a harmoniously functioning model of a supranational democracy and one where no member state should dominate any other, presumably via a strong role for the Commission.

During the convention's first few months of work, proposals flowed in from many quarters. ${ }^{27}$ There were certain similarities (but also important differences) between Brussels in February 2002 and Philadelphia in I 787 or Bonn in I948, to mention just a few conventions entrusted with shaping a new constitution for a state or group of states. ${ }^{28}$ The actors - 
governments, national parliaments, the European Parliament, the Commission and others - were all present and eager to present their ideas and defend their interests. The quality of the end result would determine whether all those absent but who mattered most - the ordinary citizens of the enlarged EU - would start feeling that the EU was with them and in their hearts, rather than above and apart from them.

By early 2003 the convention still held together well and had made steady progress in reaching its aim of presenting a joint text to the new member states within the timeframe foreseen. Thus there was now a broad consensus to draw up a constitutional treaty, a framework for which was presented at the end of 2002. EU legislation would come under a single legal entity (signifying a departure from the 1992 Maastricht Treaty on European Union) and would be drastically simplified, as would EU procedures.

A first part of the future constitution would deal with fundamental rights, EU powers and institutions, democratic government, finances and representation vis-à-vis the outside world. The framework described the EU as 'a Union of European states which, while retaining their national identities, closely co-ordinate their policies at the European level and administer certain common competences on a federal basis'. Subsidiarity would be assured by 'the principle that any competence not conferred on the Union as a constitution, rests with the member states', thus limiting the scope for institutions such as the Commission to gain undue power. A 'Congress of the Peoples of Europe' was foreseen in order to give a voice to national parliaments and to preserve subsidiarity. Countries would if they so wished be able to leave the EU, whose final name would be decided in due course.

A second part of the framework dealt with various EU policies, without seeking large modification to them, such as the free movement of goods and people, economic policy, competition and internal security. A third and final part took up legal issues, such as the continuity in relation to the European Community and the repeal of earlier treaties.

As the convention attempted to go from framework to constitution proper, several countries - notable among them France and Germany sent their Foreign Ministers to represent them. Among the first proposals they had to consider was one from the Commission, in which it asked to be given the central right of initiative in all fields relating to legislation and an almost exclusive executive authority. The Commission President should be elected by the European Parliament and confirmed by the European Council (of heads of state and government). As a counterpart, the Commission would be politically accountable before these two 
bodies. The European Parliament would be given the same legislative powers as the Council of Ministers, while the veto power within the latter would be abandoned in favour of majority decisions. A single 'Foreign Secretary' would be responsible for external relations, rather than divided between a High Representative of the member states and a European Commissioner, as at present.

In early 2003, France's President Chirac and Germany's Chancellor Schröder proposed a dual EU presidency: an EU President would be appointed by the Council of Ministers to serve as the public face of the $\mathrm{EU}$ and as its political driving force, also on foreign policy. A European Commission President would be elected by the European Parliament. The EU's 'Foreign Secretary' would work under the EU President but be based in the Commission. The French-German compromise proposal was considered as having a chance of being accepted by many other member states, since the differing French and German views - France's being more intergovernmental and that of Germany seeking a stronger influence for the EP and the Commission - rather well reflected the major strands of opinion in the $\mathrm{EU}$ as a whole.

However, the most difficult choices still remained to be made. What should be the final purpose, 'identity' and popular legitimacy of the EU questions all the more pressing given the already achieved high degree of integration? Should the EU be given more capacity for action in the international arena, such as in ensuring the success of the euro in world markets? Or was this not necessary, to the extent that member states felt they could safeguard such interests better individually or in (shifting) coalitions, such as dealing with Iraq in 2003 ?

Should the EU be a confederation along the Swiss model, a 'Europe of states'? Or should it be a federal state, a 'United States of Europe'? Or should it be a combination of the two - more federal internally via increased powers for the Commission, and more confederal in its international relations, via the intergovernmental Council of Ministers? Or should the 'community model' be sought along the lines of the present set-up, with the Commission as the engine behind final decisions to be taken by the Council of Ministers and approved by the European Parliament? What should be the balance of power between the EU institutions and to whom should they be accountable? Presumably, final answers to these questions would essentially have to be given at the truly political level, that is, at the post-convention stage of deliberations. 


\section{The EU's policing of its inner democracy: the 'Haider affair'}

In February 2000, the Austrian People's Party (Österreichische VolksPartei - ÖVP) formed a government coalition with the Austrian Freedom Party (Freiheitliche Partei Österreichs - FPÖ) led by Jörg Haider, a far-right populist who had made statements, later withdrawn, praising aspects of Hitler's rule. ${ }^{29}$ The government had come about as coalition negotiations between the ÖVP and its earlier partner, the Austrian SocialDemocratic Party (Sozialdemokratische Partei Österreichs - SPÖ) had broken down. The other fourteen governments of the EU reacted by downgrading relations with Austria, provoking a bitter debate about the meaning of national sovereignty and about whether the quest for morality as the basis for an emerging new international order should take precedence over the democratic expression of a people's will.

With the FPÖ obtaining virtually as many votes as the ÖVP in the national elections of October I999, and well ahead of the SPÖ, the coalition seemed natural enough, if it had not been for Haider's extreme remarks and his party's perceived xenophobia or even antisemitism. ${ }^{30}$ The French and Belgian governments were in the forefront of a weekend move, which by the following Monday had virtually isolated Austria diplomatically from the rest of the EU and which would continue, it was declared, for as long as the coalition remained. The French and Belgian fervour was due not only to the personal convictions of the leaders of these countries, but also the particular inroads into the political arena made by the extreme far-right Front National in France and the Vlamse Bloc in Belgium.

However, the rather hurried decision among the Fourteen also drew fire from some quarters. Why, it was asked, had it been rushed through over a weekend, without much consultation of especially some smaller EU member state governments or any consultation of national parliaments or the European Parliament? ${ }^{3 \mathrm{I}}$ Why was it made even before the new government had even been formed, let alone taken any actions that might have represented 'serious and persistent' breaches of the principles of liberty, democracy and respect for human rights, in the words of a recent EU treaty revision? Where was the respect for an EU 'subsidiarity', in this case the right of each country to decide on its own government? Would the EU have done the same to a big or central country as it had done to Austria?

The proponents of the action argued, however, that incursions by the extreme Right had to be nipped in the bud, especially in view of forthcoming EU enlargement to the new democracies in Central and Eastern 
Europe. If Europe had shown similar resolve in I933, they said, the Third Reich and World War II might have been avoided. Finally, if political Europe was to have any meaning, the political situation in any one country would have to be the concern of all, especially if it went against basic EU principles.

In the summer of 2000 a delegation of 'three wise men' was dispatched to Austria to judge the country's policies as well as the evolution of the FPÖ. ${ }^{32}$ Finding a way out had become more and more of a necessity for the Fourteen, as the sanctions were proving ineffectual and unpopular in the EU. An Austrian referendum on the sanctions was to be held in October, 2000, and it was feared that the boycott would influence a Danish referendum on the euro the preceding month in the direction of a rejection.

In the autumn of 2000, the sanctions of the Fourteen against Austria were lifted following a report by the 'three wise men'. The report said that, although the FPÖ had often used ambiguous and xenophobic language and had 'trivialised' Nazism, it had not used such language after it had joined government. The latter, the report went on, had respected 'European values' and its record on minorities, refugees and immigrants was no worse than in any other EU country. Under such circumstances, the 'three wise men' concluded, it would be counterproductive to continue the sanctions. These were subsequently lifted.

Whatever view one took, the EU would now have to follow a rather interventionist course if it was to be faithful to the Austrian precedent. Nor was it clear how such a course would work out in different EU countries with strong xenophobic or far-Right parties. The road from European union to European disunion and paralysis could be shorter than one cared to think. ${ }^{33}$

\section{Turkey and the EU}

Turkey first applied for EU membership in 1963 and soon was given association status and preferential trade links. However, it was told that membership would have to wait, until even that hope was thrown out at an EU summit in Luxembourg in 1997. The arguments raised by the EU included the as yet unresolved Kurdish question and Turkey's human rights record, which was perceived as inadequate. Turkey was urged not to try to hinder the accession of Cyprus to the EU and to improve its relations with Greece. In order to patch up relations, Turkey was invited to participate in a special Europe Conference in London in 1998, an invitation subsequently spurned by Ankara. (The conference brought 
together the Fifteen and the eleven 'first and second wave' states, but left few traces.)

When Turkey was finally included among the seven 'second wave' candidate countries in 1999, it was in part in recognition of the country's support as a NATO member during the Cold War and its key strategic position in between three restless regions: the Balkans, the Caucasus and the Middle East. A Turkey in the EU would radically increase the institutions's influence in these regions, while a Turkey outside it would correspondingly diminish it. Turkey was a major, and rapidly developing economy, with its sixty-six million people and one of the fastest growing and youngest populations in Europe. As an EU member, however, Turkey would of course also be part of the Internal Market, implying free movement of, among other things, labour. With unemployment high in many EU countries and xenophobia not far below the surface, the effects of likely large-scale immigration by Turkish workers was an issue of considerable concern to some EU members. Finally, Greece's opposition to Turkey's entry went deep, because of memories of past Ottoman domination, the conflict over Cyprus and strife over borders in the possibly oil-rich Aegean Sea. By the early 2000s, however, relations between Ankara and Athens had improved considerably. ${ }^{34}$

Turkey, for its part, was not without options. With a customs union in place with the EU since 1996, its immediate economic interests (minus the EU financial assistance that would come with membership) had largely been secured. The country was unlikely to stop playing its other cards even as an EU candidate, especially if membership negotiations were to drag on. These included closer relations with the United States, Russia, Israel and culturally and linguistically related countries in central Asia, not least in view of the oil and gas riches in and around the Caspian Sea. To the extent that these cards were played skilfully, the EU might well find that delaying Turkish entry could carry with it a cost, in that it was shut out of deals between Turkey and its new partners. Amidst all this there was, in Turkey, a strong and, some argued, growing Islamic fundamentalism. While this was not likely radically to alter the overall orientations of the country (which were largely geostrategically determined), it could still add to political instability.

By the time of the December 2000 EU summit in Nice, Turkish relations with the EU had cooled considerably. ${ }^{35}$ It was clear from a critical report by the Commission of November 2000 that the EU candidate in question was far from actual membership negotiations due to the Kurdish, human rights and Cyprus issues. Ankara responded with anger, by downgrading contacts with Brussels. It also blocked the approval by NATO 
(of which it was a member) for the EU's wholesale use of NATO resources for the purposes of its Rapid Reaction Force.

Turkey began a major reform process in 200I, one purpose of which was to prepare it for EU membership. Constitutional and legislative changes were made ensuring gender equality, liberalising party and trade union legislation and consolidating civilian control over its National Security Council. In 2002 the death penalty was abolished, the Kurdish language permitted on radio, television and in education, and religious rights protected.

The reforms were enough to extract from the $2002 \mathrm{EU}$ summit in Copenhagen a promise that a decision would be taken by the end of 2004 on the principle and date of the start of membership negotiations with Turkey, provided that the reform process was continued and implemented and progress reached on the issue of the still-divided Cyprus. Behind the EU's commitment lay strong US pressure and Turkey's agreement to lift its veto, referred to above, against letting the EU's Rapid Reaction Force use NATO resources - an issue that had hampered the Force's realisation since the I999 Helsinki Summit.

\section{The inner logic of EU enlargement: ten new members in 2004 and more in line}

For the European Union, enlargement is central to its very essence and raison d'être. Previous chapters have related how the United Kingdom, Denmark and Ireland joined in 1973, followed by Greece in I981, Portugal and Spain in 1986, and Austria, Finland and Sweden in 1995.

It had been clear already in the early I990s that the newly liberated countries in Central and Eastern Europe would eventually join, the only question being when this would be possible given the European Union's rather exacting acquis communautaire and the still low economic output of the countries in question. As they strengthened their democratic institutions, they were able to join the Strasbourg-based Council of Europe in growing numbers, but one of their main ambitions, apart from joining NATO, was EU membership.

It was also obvious that the $\mathrm{EU}$, in order to be able to include many new members, would have to reform its inner functioning, both as regards institutions and financing. The former were essentially the same as, and construed for, an EU of six or perhaps at most a dozen or so members, as had been the case between I986 and I994. The finances would have to be reviewed as the candidate countries were comparatively poor and had large farming populations.

The EU summit in Amsterdam in 1997 had agreed to the principle of 
enlargement with the number of 'first wave' new members - considered to have reached furthest in economic and political development - soon crystallising at six: Cyprus, the Czech Republic, Estonia, Hungary, Poland and Slovenia.

The 1999 Helsinki Summit - in a departure from the earlier 'small bang' enlargement plans to a 'big bang' variant - widened the circle of recognised candidate countries from six to thirteen by including Bulgaria, Latvia, Lithuania, Malta, Romania, Slovakia and Turkey, even though negotiations would start with Turkey only at a later, unspecified date. The Nice Summit in 2000 concentrated on readying the EU from the institutional and decision-making points of view for such a further enlargement.

The EU would have to enlarge in its capacity as the main unifying force in Europe, even as nobody could predict where the EU's 'final' borders to the east and south-east might some day lie. Unlike earlier such unifying forces - a France under Napoleon or a Germany under Hitler - this was not an empire in the making, but an institution in which countries joining would do so voluntarily and be part of the management. Some sovereignty - unknown how much - would have to be abandoned, but it would presumably be the same for all members, new and old.

A power vacuum that had arisen with the disappearance of the Soviet Union and its area of influence in Central and Eastern Europe had disappeared and needed to be filled. NATO, a pure defence and security organisation, would not suffice. There was therefore a logic which pushed the EU toward enlargement far into the east, up to the borders of Russia (and a Ukraine not yet deemed fit for candidacy), a country that would have to be brought into as a close a partnership as possible with the EU. The US was also supportive of the effort, as it saw the EU as a stabilising force largely serving its own security concerns and presence in this part of the world, as underpinned by NATO enlargement.

The candidate countries, especially those that had been under Soviet sway, were on the one hand keen to preserve as much as possible of their newly won national sovereignty and freedom of action - achievements they might have partly to give up along with EU membership. On the other hand, there was the political and security protection offered by the EU and the prospect of important EU financial support for these countries' agricultural sectors and poorer regions. The EU still had the aura of Europe's 'rich men's club' and membership in it was seen as a sign of economic and political success, of having 'made it' into established Europe. Meanwhile, during the candidacy process, the goal of membership would give these countries' foreign policy and economic reform efforts 
stability and direction. Less clear to the candidates was perhaps the fact that membership would not mean any automatic acquisition of prosperity but would rather imply a continued commitment to the, increasingly, stringent acquis communautaire as regards, for instance, the opening of markets and the reduction of domestic subsidies.

In 2000, the European Commission, which negotiated with the twelve candidates on behalf of the EU, announced that it hoped to conclude the talks, focused on thirty-one 'chapters' of the acquis communautaire by the end of 2002, so that a formal target date for entry could be fixed for 2004, ahead of the elections for a new European Parliament foreseen for that year. By mid-2002 this forecast was confirmed by the Commission, even though the number of likely new members in the 'first wave' had now shrunk from twelve to ten following a decision at the $200 \mathrm{I}$ EU summit in Brussels. ${ }^{36}$

The prospective membership of Lithuania and Poland presented the EU with a major problem in its relations with Russia. The Kaliningrad region - a part of the former East Prussia (Königsberg and surroundings) sandwiched between Lithuania and Poland, ceded to the Soviet Union after World War II and now forming part of Russia - had become geographically separated from the rest of that country as a result of Lithuanian independence. With Lithuanian and Polish membership of the EU - and hence participation in the Schengen Agreement foreseeing the free movement of people and goods across borders - the one million inhabitants of Kaliningrad would not be able to move freely between the region and the rest of Russia. Instead, as non-EU citizens, they would need a visa. This, Russia argued, would mean an unacceptable infringement of their human rights. Russia asked for 'corridors' through Lithuania and Poland, something which, however, neither of these two countries nor the EU felt they could accept. A solution was becoming urgent, both for EU-national relations and for the people of Kaliningrad who, isolated from Russia and the outside world in general, were sinking into greater and greater poverty.

There were tensions among the EU member states as to the extent and timetable of enlargement. The UK was in favour of wide and speedy enlargement, believing that the resulting larger heterogeneity would weaken any feared 'deepening' of EU integration. The Nordic EU countries Denmark, Finland and Sweden - were eager to include the Baltic states (Estonia, Latvia and Lithuania) as well as Poland - as was a Germany keen on stability to its east. All EU members agreed on the need eventually to include also Bulgaria and Romania to promote stability in South-Eastern Europe. 
However, some EU members feared that too wide and speedy an enlargement would hasten the arrival of the day when an increasingly financially strained EU would have to cut its regional and agricultural funds to the older members. Countries like France, Portugal, Spain, Greece and Ireland therefore emphasised the necessity for the candidates to meet all parts of the acquis communautaire before accession - a requirement that would tend to slow down the process - and also wanted to make support levels lower for new members than for the current ones. The candidates, by contrast, insisted on a number of temporary exemptions from the acquis and on uniform financial-support models to avoid becoming 'second class' EU members. Meanwhile, net contributors to the EU, and in particular the biggest net payer Germany, insisted on not having to pay (much) more into the EU budget following enlargement.

The EU's long-awaited 'big bang' enlargement came at its summit in Copenhagen in December 2002, when it decided to admit ten new members by May 2004: Cyprus, the Czech Republic, Estonia, Hungary, Latvia, Lithuania, Malta, Poland, Slovakia and Slovenia. The EU's population would increase by 70 million to over 450 million. Following the agreement to the enlargement by the European Parliament in 2003, the accession treaty would have to be ratified by all the fifteen current member states (and perhaps submitted to referenda in a few among them). The EU would also monitor the implementation of the commitments given by the future members, including reforms promised in the administrative and judicial domains.

Meanwhile, negotiations would continue with Bulgaria and Romania, with a possible date of accession set for 2007. Finally, as has been mentioned, an attempt would be made in 2004 to set a date for the start of membership negotiations with Turkey.

Negotiations with the ten candidate countries were difficult up until the Copenhagen Summit. They focused on the level of agricultural and regional support to be given to the new members and on whether compensation to their farmers would be the same as that paid to their colleagues in the 'old' member states. The added costs to the EU for the 2004-6 period were budgeted at around $€_{4} \circ$ billion.

The Copenhagen Summit was truly historic, as had been the NATO Prague Summit a month earlier, where it had been decided to invite seven new members to join the defence alliance. The Copenhagen Summit came only nine years after the EU summit of 1993 in the same city, where the so-called 'Copenhagen accession criteria' - now met - had been agreed, and twenty-one years to the day after communist Poland had proclaimed martial law in I98I. As in Prague, the speeches referred 
to the 'reunification of Europe that had been divided at Yalta' in I945. Even the issue of the Kaliningrad region was resolved in parallel negotiations among the EU, Russia and Lithuania. ${ }^{37}$

The EU's enlargement was unlikely to stop at the ten invited in 2002 or those foreseen for the years thereafter. At least some of the countries in the Balkans would be next in line, as witnessed by the many association and assistance agreements concluded with the countries of the former Yugoslavia in particular. Since the Kosovo conflict, the EU had been paying much greater attention to the region. The Stability Pact, jointly administered by the EU and the World Bank, was not only about giving money, but also about enhancing trade and investment within the region - a difficult task given its recent and not so recent history of conflict. The EU, like the rest of the international community, expected, however, that borders would not be changed, as they would be if Kosovo or Montenegro were to leave what remained of the Federal Republic of Yugoslavia (which in 2002 decided to change its name to Serbia and Montenegro). The fear was that, if this happened, many other borders in the region would be called into question.

Finally, non-EU countries in Western Europe had begun to rethink their position, as the inconveniences of remaining outside the EU began to be felt. The EU's European Economic Area (EEA) Agreement concluded with Iceland, Liechtenstein and Norway in 1994 gave the latter free access to the EU's Internal Market in most areas (though not fisheries) but little say in decisions. The situation could only worsen in an EU which in 2004 would go from fifteen to twenty-five, especially as the EEA countries would have to pay much more into the EU's 'Cohesion Fund' used to assist the less wealthy new members. The EEA countries would also face new trade barriers with the new EU members, with which they had, paradoxically enough, already concluded bilateral free trade agreements via EFTA. Iceland treasured its exclusive control over its fishing waters, but other economic areas suffered from being outside the EU. Norway also had important fisheries interests to defend and would be a major net payer once inside the EU due to its oil wealth. Still, even there doubts about the advantages of remaining outside began to arise. Popular referenda on membership in those countries could not be excluded in some future.

Switzerland's relations with the EU had been defined in a so-called 'Bilateral I' agreement of 2002 , but difficulties had emerged in the negotiations for a future 'Bilateral II' treaty, especially over customs issues and the taxation of income from interest to be paid by EU citizens on capital held in Swiss banks. A Swiss referendum on EU membership 
was not, however, on the cards for a variety of reasons. These included opposition against membership by a seemingly solid majority of the Swiss and difficulties in reconciling Swiss direct democracy with the EU's method of functioning.

\section{Reform of the Common Agricultural Policy and the aid to regions}

One area in great need of reform was the EU's Common Agricultural Policy (CAP). Ever since the crucial decision was taken by the EEC in the late I950s to engage in price support (a guaranteed price for each unit of various commodities) rather than income support (a guaranteed income regardless of production), the EU had had to compensate for one administrative shortcoming in the system by adding another. Big farmers were favoured, deliberately at first so as to rationalise farming by creating larger units and forcing smaller farmers off the land into other occupations. This worked as long as production was not in excess, i.e. up until the mid-I960s. However, as from the early I970s, when excess production of dairy products and beef in particular rose to worrying levels, the EU had to resort to dumping on the world markets (much to the irritation of North Americans, Australians and others), and pay for it through export subsidies. (The CAP and other agriculture-related expenditure still today accounts for about half of an EU budget, which has in the meantime become much bigger. ${ }^{38}$ )

The early I990s saw various limited EU efforts to reform the CAP: cuts in price support beyond certain production levels; 'set-aside' programmes, i.e. payments to farmers for letting land lie fallow; reforestation and support for environment protection initiatives; and a cutback on export subsidies under international pressure (notably US). ${ }^{39}$

In 1997 the Commission, as part of its more general Agenda 2000 for revamping various EU policies, proposed further cuts in price support for main crops in order to return EU agriculture slowly to the free market and to lower prices for consumers. It further suggested greater reliance on supporting farmers' incomes, signifying a return to an idea discarded in the r950s. The new aim would be to help smaller farmers stay on the land and thereby counter the flight to the cities where jobs were now scarcer, and to encourage local food varieties and higher food quality.

Reform of the CAP was all the more urgent in view of the forthcoming EU enlargement to the countries of Central and Eastern Europe with their large and comparatively poor farming populations. At the same time the EU would have great difficulties assuming any major extra outlays as a result of enlargement, especially since the new countries 
would all be net beneficiaries from the EU budget. With uniform and unchanged CAP payments throughout an enlarged EU financially almost impossible - and with reduced overall CAP payments politically difficult vis-à-vis farmers in the present EU member states - a nonuniform CAP giving less to the farmers of the new entrants might be the only way out.

The 1999 Berlin Summit, as described earlier in this chapter, showed that resistance against changes to CAP payments was fierce, not only from EU members that stood to gain the most, but also from strong and well-organised farming interests. Another idea - the 'renationalisation' of the CAP (i.e. its abandonment) - was floated by Germany in the leadup to the Berlin Summit, but it was abandoned after heavy French resistance. Given the difficulties of reforming the CAP in any meaningful way, the enlarged EU was likely to face both a costly system and considerable excess production, especially in the meat and dairy sectors.

A new Commission proposal in 2002 suggested an even greater 'decoupling' of agricultural payments from farm production. A set sum would be paid to each farm, the size depending on past production and the farmer's contribution to environment protection, landscape improvement such as forestation, animal welfare and village renewal. This would lead to less production of commodities in excess, such as dairy products and beef, and hence to fewer export subsidies, considered to be in violation of World Trade Organisation rules. The new proposals would, however, keep intact many other features of the traditional CAP, such as price guarantees and levies on imported food. Meanwhile, farm aid to new member countries would be phased in as from enlargement, starting with a quarter of the EU level in 2004 and reaching it in 20I3. The Commission's proposal led to fierce reactions on the part of several EU governments with important CAP payments to defend, especially France.

In 2002 France managed to rally Germany - normally a country in favour of CAP reform but now politically weakened over the Iraq crisis in particular - and eventually also the EU around a proposal to delay any strict limit on CAP spending and further reform until 2007, rather than the earlier 2004 date sought by the European Commission through countries like the United Kingdom and Sweden. ${ }^{4 \circ}$

The European Commission, eager to achieve reform, fought back, however, pointing out that an unreformed CAP of massive export subsidies and import restrictions might scuttle the ongoing World Trade Organisation's round of negotiations - the Doha Development Agenda where other essential EU interests, such as in the services sector, were at stake. Agriculture was now moving to the very centre of international 
politics, with developing countries and major agricultural producers such as Australia, New Zealand and Canada pressing the EU, and increasingly also the US, to give up subsidies and let more imports in, or risk a collapse in trade negotiations and a brake on world economic development. The Commission, representing EU member states in the trade talks, faced a formidable balancing act.

It was similarly difficult to reform the EU's regional assistance programmes. At the beginning of the EU's history, regional aid was devoted to the assistance of the truly poorest regions of the then Six, such as the Italian Mezzogiorno or the eastern parts of the Federal Republic of Germany that had lost their links with the east due to the Iron Curtain. However, it was increasingly being used to compensate other regions or even countries which felt they gave much more to the EEC-EC than they received in return (this was the case with the British rebate). For every new enlargement, starting with Greece, regional support was used for such compensatory purposes by the existing member states, who saw their own receipts threatened if they had to be shared with newcomers, unless of course the overall EU budget was increased and they could receive extra funds. For the Twelve-to-Fifteen enlargement, a new Cohesion Fund was introduced, principally benefiting Greece, Ireland, Spain and Portugal. The Berlin Summit of I 999 meant both a restriction on the growth of regional outlays and a concentration on the poorest regions.

The EU's regional support amounting to some $€_{3} \circ$ billion per year (over 30 per cent of the EU budget) would face particular strain. Whereas in the EU of twelve member states one-sixth of the population lived in so called 'cohesion countries' (a per capita income of less than 90 per cent of the EU average - Greece, Portugal and Spain), that proportion would rise to one-third in an EU of twenty-seven member states. Similarly, in an EU of twenty-seven member states, the poorest Io per cent of the population would have a per capita income of only about one-third of the EU average, as opposed to close to two-thirds of that level in the EU of fifteen states. Not only would this mean that more regional funds would have to be made available, but the 'cohesion countries' of the EU of twelve member states might receive less.

\section{The fraud problem}

CAP and regional aid are among the EU programmes most afflicted with fraud and payment 'irregularities', which are estimated to amount to close to $€_{7}$ billion per year, or around 8 per cent of the EU budget. The EU's Court of Auditors in Luxembourg - an institution with great expertise 
and a strong will to remedy the situation but with a limited remit, in that it can only report but not initiate prosecution - regularly points to wrongly waived customs duties, export funds paid 'in error', and subsidies to farmers for non-existent or already subsidised set-aside land, for dreamt-up herds of cattle, olive groves and other products, or for surpluses of already rotten fruit. The absence of border controls through the Internal Market, coupled with VAT payments only at the point of delivery of goods (instead of at the point of departure), is reported to give rise to massive fraud involving organised crime, lorry drivers, transport companies and customs agents.

Even where there is no outright fraud, the Court has found many examples of inefficient use of funds due to poor planning, co-ordination or evaluation of projects. For example, regional support is often invested in ways that run counter to environmental objectives. Aid to non-EU countries is often inefficient because of a lack of ability of recipient countries to absorb it.

Even though the magnitude of fraud is thought to have come down following stricter procedures (many of them called for by the Court of Auditors) and even the use of informers, it still eats like a cancer at the whole EU edifice, affecting the morale of EU tax payers while building up the bank balances of profiteers. It is, however, difficult to see how it can be radically reduced, since normally the controlling and disbursing authorities are national (over three-quarters of all EU spending is administered by the member states), but the funds come from the EU as a whole. There is no obvious reason why a member state should devote all the effort it takes to check on the use of money which is mainly paid by fellow EU countries. It cannot be excluded that national controllers are even tempted to turn a blind eye to the problem. At issue is the unnecessary centralisation of payments, and the unaccountability of the central authority, the European Commission, before a popularly elected assembly that has greater powers than those at present enjoyed by the European Parliament. ${ }^{4 \mathrm{I}}$

\section{The risk of excessive uniformity}

One problem for the EU is the rigidity of its legislative framework - the 80,000-page-thick acquis communautaire. A national parliament, acting under popular pressure or not, can with relative ease cancel or modify a law which has outlived its usefulness. However, to modify or cancel a directive is much more difficult and lengthy, requiring that several EU governments view things the same way and present a corresponding 
proposal for change to the Council of Ministers; that the latter authorises the Commission to study the proposal and possibly prepare a new draft directive for submission back to it; that the new text meets with the approval of the required majority of governments on the Council of Ministers (or them all, as the case may be); and, finally, that the new directive is transposed into national law by all the countries.

Meanwhile, the world goes on at ever more tantalising speed, which would require more rapid, not slower, adaptation of the legislation. The EU seems to be caught in a time warp, stuck in an approach to life more in line with the assumed exigencies of central planning, uniformity and secretiveness of the I950s than with decentralisation, flexibility, public openness and the diversity associated with present times. Europe derived its strength and dynamism over history from the inability of one power to dominate all the others, thus preventing it from falling into the decline of an Ottoman or Ming Empire. The price Europe (and the world) had to pay were wars, of which the last two nearly destroyed it. The question for Europe today is whether it can find a system with which it can preserve its dynamism by enabling its various regions to experiment with different social and economic models, and at the same time to maintain peace. (This is all the more important as the stagnation that is likely to follow from excessive uniformity may itself engender conflict.)

One example of the above has been in the social field, where the Social Protocol to the Maastricht Treaty was integrated into the EU acquis communautaire, following signature and ratification by the last remaining EU member to do so, the United Kingdom, in $1997 .{ }^{42}$ The UK made it clear that it would continue to follow its own, more flexible - many would say less social and less employee-friendly - social policies regardless. But the end result of further EU legislation in this field flowing into the breach opened by the Social Protocol may well be the inability of any and all to adapt the EU to new circumstances. ${ }^{43}$

The Common Agricultural Policy has already been mentioned. Here, uniform principles collide with extremely diversified farming situations, leaving as a result over many decades a myriad of ad hoc exceptions that render the overall CAP regime largely impenetrable to the outsider and hence the more difficult to change.

Subsidies, also in principle barred in the EU (although still frequent in many sectors), are a special case. From a single market point of view, it is of course desirable to equip a non-democratic European Commission with powers to prohibit a country, say, France from subsidising Air France or Crédit Lyonnais, or a German Land from supporting a local Volkswagen plant. However, if the French or the German people 
happen to want this to happen, they are in principle prevented from doing so by the EU, acting through the Commission. In a different type of EU, countries would have been free to subsidise whatever they wanted (as the individual states in the US can do), on the understanding that they would eventually pay the price in the form of slower growth due to higher taxes and less efficient companies (as a result of being subsidised).

Another example comes from the economic and trade arena. Germany, a nation particularly fond of bananas, traditionally imported them from whatever country offered the lowest price, whether or not it was linked to the EU through the so-called Lomé Agreement giving preferential trade status to a large number of so-called ACP (African, Pacific and Caribbean) countries. However, a judgement by the European Court of Justice in Luxembourg ruled that this was a violation of Lomé, in spite of Germany's protests that in buying from a country such as Costa Rica it only respected GATT-WTO principles. The economic interests of the Germans (who consume more bananas per person per year than any other EU member) and of other EU citizens were sacrificed on the altar of the economic interests of other EU and ACP nations and the uniformity of consumption, through a decision of a supranational court essentially deliberating behind closed doors. ${ }^{44}$

To some, the banana case and others similar to it highlighted the risk posed by excessive EU constraints to more open world trade and to the welfare of EU consumers. To them, an EFTA arrangement in place of the EU's customs union would never have created the problem in the first place, as there would have been no common external tariff on bananas or other products. Others maintained, however, that the EU must show solidarity to its own producers and to those in the ACP area, whether it be through trade preferences, regional support, the CAP or development assistance through the Lomé Convention, which from I990 to the year 2000 disbursed some 24 billion ECU to the ACP region.

The EU's fishing policy - 'Blue Europe' - shows the risks caused by excessive uniformity vis-à-vis the resource itself. 'Blue Europe' is based on the noble EU principle that in a single market one must essentially share everything, in this case the fish stocks, whether they are inside or outside the traditional fishing zones of individual EU countries. However, in the I980s it was discovered that free and equal access for all Spanish fishermen in British waters, British in Spanish and so on depleted stocks, since everybody suspected everybody else of catching more than they should and therefore did likewise. Before, each country managed its fish resources (sometimes giving quotas to foreign fishermen) and had an interest in ensuring the long-term stability of stocks. 
Now, however, nobody knew who was in charge, unless it was a European Commission trying to act as an honest but largely ineffectual broker who found it easier to say 'yes' than 'no' to the various demands for more fishing rights coming from all sides.

Only a complicated system of EU quotas, inspectors, zones and fishing licences has managed to keep fish stocks at just above the extinction level - with recriminations over 'quota-hopping' by neighbours and occasional shoot-outs between coastguard vessels of different nations. Again, less emphasis on the 'communal' aspects of the European community idea and greater recognition of the specific characteristics of nature, and of nations, might have led to more (and cheaper) fish on the tables of EU consumers and less aggravation among fishermen and governments. $^{45}$

\section{Unemployment: too high for comfort}

National economies in the EU - and elsewhere in Europe - have to grow by between 2.5 per cent and 3 per cent a year in order to keep unemployment from rising. Any growth rate below that range will tend to increase unemployment, while any rate above it will tend to reduce it. This is so because the implementation of the EU's Internal Market, and the continuing opening of markets under the World Trade Organisation process, will increase competition in many sectors of the economy and cause many firms to go out of business, 'downsize' their workforce or 'outsource' their production to countries with lower labour costs. As a result, many people will lose their jobs. Those with few qualifications women, school leavers (especially those with interrupted studies), elderly people and even the not so elderly - are particularly exposed. Only with sufficient growth will new companies be created and established firms grow sufficiently to create new jobs to replace those that have disappeared. It has therefore become essential for EU member countries to show sufficient economic growth. Several Commission White Papers on the subject have seen the light of day and many EU summits have been devoted to it, leading to 'job pacts' and 'processes' meant to lead to lower unemployment. ${ }^{46}$

While economic growth came relatively easily in the 1950-70 period, with rates of 5 per cent or more, it became more difficult to reach them ever since the first oil crisis of 1973-74. Long-term unemployment that is people being out of a job for several years - shot up in the I980s despite resumed growth and has stayed high ever since. Job creation also began to lag behind the growth of the workforce (a result of the 'baby 
boom' of the I940s and I950s), causing overall unemployment to grow. The entrepreneurial spirit for whatever reason seemed to prosper less in the EU than, say, in the United States, where new jobs absorbed virtually all of an even more rapidly growing workforce. ${ }^{47}$

Unemployment in the EU in the I990s remained high, at around 9 per cent. The early 2000 s saw a reduction to around 7.5 per cent, assisted by economic integration and increased intra-EU trade resulting from the euro's introduction in 1999. However, as European Union growth in 2002 slowed to less than I per cent, with uncertain prospects for 2003, unemployment looked set to rise, especially in key countries like Germany and France.

Many problems remained. Labour markets were recognised as being too 'rigid', meaning that companies could not shed workers as fast or as cheaply as they would wish. Aware of this, they hesitated to hire when the going was good. High extra-salary costs further discouraged hiring. The start-up of companies was a complicated, lengthy and costly process in some countries. Taxes on companies were often so considerable as to deprive them of sufficient capital to grow and hence employ. ${ }^{48}$ Taxes on individuals in many countries were too high to leave them with enough money to spend on goods and services, and hence permit companies to profit and grow.

Many of the jobless, meanwhile, remained outside the labour market so long that they lost the skills, motivation and self-confidence they would have needed to re-enter it. This raised the 'structural' unemployment rate, that is, the rate below which even an economy in full expansion cannot readily recruit from the pool of the unemployed, swelled by a growing number of people sent into 'early retirement'. Many jobless would not even make more money if they worked, or the difference might be marginal, and so would not take jobs offered to them. In the EU of the early 2000 s, the structural rate of unemployment, below which the economy would not be able to recruit workers without igniting inflation, lay at around 8 per cent of the workforce, as opposed to 4 or 5 per cent in the United States.

The unemployment picture in the EU was, however, far from uniform. In Ireland it had come down from about I 5 per cent in the early I990s to around 4 per cent in the early 200os, as the country profited mightily from the 'new economy' and the ICT (information and communications technologies) revolution. Spain, another 'tiger' in the new euro-zone context, had managed to reduce its unemployment from I 6 per cent in the mid-I990s to around I I per cent in 2002. The UK's unemployment in 2002 remained at about 5 per cent, even though with large differences 
between regions. The situation in 2003 was more serious in big Euroland countries like France, Germany and Italy, with rates close to or in the double-figure range. The labour markets of these countries seemed particularly impervious to the increased 'flexibility' sought by, for instance, the European Commission and the OECD.

Longer-term prospects for the EU were not altogether bleak, however. Labour market reforms in the direction of greater flexibility were proceeding in many countries, setting an example to others. EU enlargement would increase trade and investment in the region and help to reduce the comparatively high unemployment rate in the new member countries. Finally, many more people in the EU would reach retirement age as from about 2010 and there would be fewer younger people to take their place, leading to an automatic lowering of unemployment (but also to many other problems discussed in Chapter ıo).

\section{Notes}

I In Reflections on the Revolution in France, I790.

2 The new Labour government that came to power in May I 997 under Tony Blair made this concession, which its Tory predecessor under John Major had refused. For example, the provisions for an EMU in the 1992 Treaty on European Union required British acquiescence (in exchange for a British opt-out clause), whereas a future similar project could well be taken without the consent even of a large EU country.

3 These increased powers of the European Parliament included: individual approval of a new President of the Commission; the possibility of establishing common rules, or at least principles, for the election of European Parliament members in the different countries; a greater say in sanctions against a member state in the event of serious human rights violations; and the right, within certain limits, to determine the status of rights of its members.

4 Presumably, the reformers took their cue from the British historian C. Northcote Parkinson, who in his Parkinson's Law ( $1957, \mathrm{p} 49$ ) postulated that no committee can succeed with more than twenty members since, at that point: 'It is finished. It is hopeless. It is dead.' On a more serious note, the number of Commissioners is highly arbitrary. The fact of having so many Commissioners often leads to confusion and paralysis, especially where economic and political relations overlap, as they increasingly do. Thus, for example, the Commissioner in charge of EU enlargement risks clashing with the colleagues responsible for external trade, transport, agriculture, development co-operation and possibly others.

5 In October 1999 an EU summit in the Finnish city of Tampere agreed to speed up work aimed at the creation of an area of common EU law in such fields as asylum, migration and the fight against terrorism, financial crime, 
organised crime, drugs, the trade in human beings and child labour.

6 Some observers, such as Shaw (I998, pp. 63-86), saw the Amsterdam Treaty as just as Byzantine as the Maastricht Treaty, and as an inconclusive way of restoring the EU's legitimacy following the latter's ratification hurdles: 'Amsterdam - following Maastricht - was the culmination of a growing legitimacy crisis in which all aspects of integration - processes, procedures, institutions, leadership, goals and raison d'être - were thrown into serious question for the first time in 40 years ... But real simplification requires something more than these forms of tinkering at the margins'.

7 The Cyprus issue presented many complications for relations between the EU and Turkey. The EU had made it a virtual condition for membership that the island overcome its division, since I974, into a Greek-speaking part in the south (internationally recognised) and a Turkish-speaking part in the north (recognised only by Turkey and a handful of other countries). This might, however, be used by Turkey to stall a negotiated settlement and thereby unduly influence Cypriot membership. The EU tried to counteract this by making Turkish rapprochement to the EU conditional on progress on Cyprus.

8 The Stability Pact for South-Eastern Europe was established in I999 at the initiative of the European Union. Its aim is to 'foster peace, democracy, respect for human rights and economic prosperity in order to achieve stability in the whole region'. It is led by a Special Co-ordinator and operates via different Working Tables dealing with democratisation and human rights, economic reconstruction and security. Its membership includes the EU member states, other west European countries, the non-European Group of Eight (G-8) countries (Canada, Japan and the United States) and several international organisations.

9 The 'Internal Reform IGC' was to base its work, among other things, on a report presented by the so-called 'Dehaene Committee' in autumn I999. The report proposed extended majority voting as a way to avoid gridlock. Furthermore, it suggested that future treaties be divided into two parts: one containing fundamental principles to be ratified by all member countries; and another dealing with more detailed policies that could be changed through majority vote. This would facilitate any modifications necessitated by new circumstances.

In parallel to the above reforms, Commission President Prodi presented, in March 2000, a far-reaching administrative and structural reform of the European Commission. The competence of Commission staff would count for more than nationality (i.e. staff quotas for the different member states) in terms of recruitment and promotion. Greater staff flexibility was to be encouraged. The cabinets of Commissioners were to be made more international', i.e. less dominated by one nationality (that of the Commissioner in question) and would be made more transparent (thereby reducing the chances of the mismanagement of EU funds). An independent auditing unit was to scrutinise financial management. External agencies were to take over 
certain executive tasks. A charter was to be created to help protect whistleblowers, along with a revised code of conduct to guide Commission staff in their work. The EU should come closer to citizens through delegation of tasks and decentralisation. The Commission should limit itself to core political tasks that would move integration forward, especially in the shaping and implementation of legislation. Even some of these, such as anti-cartel activities, should be pursued in greater contact with national authorities.

Io The army corps was to consist of up to fifteen brigades and would be supported by around five hundred aircraft and fifteen naval vessels. It was not yet clear to what extent the force would draw materieal from the existing Eurocorps in Strasbourg (with Belgium, France, Germany, Luxembourg and Spain as members). The hope of fielding a fully fledged Rapid Reaction Force by 2003 turned out to be unrealistic, however, owing to major lacunae in the military capabilities needed. EU sources spoke of $20 \mathrm{I} 2$ as a more realistic timeframe for full ESDP operability.

I I The Western European Union (WEU), originating in the pre-NATO days of I947-48, became the expression of the West Europeans' ambivalence as regards their own defence needs. Should it be within NATO or separate from it? However, even during the WEU's 'somnolent' years in the I970s and the I980s, it reflected, at various times, the 'European pillar of NATO' and the beginnings of a 'European defence identity', which would find its first expression in the communiqués issued at NATO's fiftieth anniversary. The WEU could be said to have prepared the ground for possible future Kosovotype interventions under exclusive European management. See, for example, Deighton and Runacle (I998).

The Western European Union handed over its operative security functions to the EU at the end of 2000 . However, the EU would not take over the WEU's collective security guarantee, in deference to the non-WEU members Austria, Finland, Ireland and Sweden. In this sense, the WEU would continue to exist.

I 2 A Policy and Security Committee was to exercise the political control and strategic direction of military operations in a crisis, taking its instructions from the EU's Council of Ministers meeting at the level of Foreign Ministers. It was to be assisted by a Military Committee consisting of Chiefs of Staff of EU member states and a Military Staff coming under the Council of Ministers and consisting of representatives of all branches of the armed forces. It would assume the conduct of military operations.

With the virtual disappearance of the WEU, European defence policies had become a purely intergovernmental affair, with the European Parliament having a right only to be informed, not consulted. National parliaments of the EU Fifteen, however, did not have the right to be informed, even though they alone had the formal right to engage their nation in war. The EU's 'democratic deficit' in the security and defence area could therefore be said to have been aggravated by the WEU's shrinking role. It was not 
clear how the situation could be remedied, especially under the EU's new secrecy rules.

I3 Germany's defence allocations, which from I970 to unification in I990 stood at between I7 and 20 per cent of the federal budget, in I 999 amounted to only 8.7 per cent. Between I990 and 2000, the Bundeswehr budget was reduced by over 20 per cent in real terms. The budget for 2000 was down a further DMr.7 billion from I999, to DM45.3 billion. No reversal of the trend was likely unless spurred on by the new European Security and Defence Policy. Germany's defence reform effort was rendered more difficult by its continued reliance on obligatory conscription (now abandoned by both France and the United Kingdom) (Rühle, 2000).

To illustrate the difference between US and EU military capabilities, the US - with 276 million people and a GDP of about $\$ 9.2$ trillion - in 2000 had a military budget of $\$ 283$ billion and a total troop strength of $\mathrm{I} .37$ million soldiers. The fifteen EU member states - with 376 million people and a GDP of $\$ 8$ trillion - had combined military outlays of only $\$$ I 65 billion ( 58.4 per cent of those of the US) but a troop strength of $\mathrm{I} .8$ million soldiers. EU military capability, however, was considered to be less than 20 per cent of that of the US. (Source: International Institute for Strategic Studies: 'Military Balance 2000/200I'.)

I4 Rearmament need estimates by Professor R. Seidelmann of Göttingen University, Germany, given at a Cicero Foundation Seminar on the European Security and Defence Policy, Paris, December 2000.

I 5 Increased military spending may not be harmful to economic growth under all circumstances, as the post-World War II period in Western Europe demonstrated. This is a complicated issue involving such factors as whether and how militarisation affects trade and investment, labour supply, the state of technological development, and spin-off effects from the military to the civilian sector. For instance, the longer-term effects of the Kosovo conflict on the region's economies or on those in Europe as a whole (especially those of NATO members) are not yet clear.

I6 The thirteen candidates were Bulgaria, Cyprus, the Czech Republic, Estonia, Hungary, Latvia, Lithuania, Malta, Poland, Slovakia, Slovenia, Romania and Turkey.

I7 This is the central thesis contained for instance in Milward's book The European Rescue of the Nation-State (2000, p 3), where he sums up his argument in these words: 'The European Community has been [the nationstate's] buttress, an indispensable part of the nation-state's post-war construction. Without it, the nation-state could not have offered to its citizens the same measure of security and prosperity which it has provided and which has justified its survival. After I945, the European nation-state rescued itself from collapse, created a new political consensus as the basis of its legitimacy, and through changes in its response to its citizens which meant a sweeping extension of its functions and ambitions, reasserted itself as the fundamental 
unit of political organisation. The European Community only evolved as an aspect of that national reassertion and without it the reassertion might well have proved impossible. To supersede the nation-state would be to destroy the Community. To put a final limit to the process of integration would be to weaken the nation-state, to limit its scope and to curb its power.'

Furthermore, it is significant that the EU's High Representative for Security and Foreign Policy is also Secretary General of the Council of Ministers, which represents the governments of member states. Finally, the Union's new Rapid Reaction Force likewise serves under the Council of Ministers, rather than the Commission.

I 8 The pre-Nice 'weighting' of votes in the Council of Ministers had been ten for the 'Big Four' against two for the smallest country, Luxembourg. Nice thus meant a reduction in the weight of the smallest country to the biggest from $I-5$ to $I-7.25$. It was not clear, however, that Nice would produce an EU better capable of overcoming its earlier difficulties in taking decisions. This was so because the new weighting still permitted any of the bigger countries to block decisions by alliances with just a few smaller ones, and because the 'unanimity areas' were not greatly reduced in number (since any country could veto the transformation of their own favourite veto area into a 'non-veto' area). There is even an 'olive oil' veto minority of 68 foreseen for Spain (27), Italy (29) and Greece (I2) to defend the particular interests of these three countries. After enlargement to twenty-two countries, the total number of votes would go from the present 237 to 345 , with 27 for a bigger new member state like Poland and 3 to a small country like Malta.

I9 Speech at the Humbolt University in Berlin, I 2 May 2000.

20 Press conference by Joschka Fischer, Minister of Foreign Affairs of Germany, Berlin, I 3 May 2000.

2I Speech before the Western European Union in Paris, 30 May 2000.

22 'Streitgespräch Fischer contra Chevènement', Die Zeit, No. 26, 2000.

23 Prowse, Michael, 'An Unbeatable Bargain in the Making', The Times, I3I4 May 2000.

24 Lord Howell of Guildford, 'Maybe what europe needs is less integration', International Herald Tribune, I I July 2000.

25 Siedentop (2000).

26 The convention was led by a twelve-member praesidium. The Chairman, Valéry Giscard d'Estaing, was assisted by two Vice-Chairmen, former Italian Prime Minister Giulio Amato and former Belgian Prime Minister Jean-Luc Dehaene.

27 In February 2002 the British government proposed that a 'statement of principle' be prepared specifying the division of powers between the EU and national capitals, following which national parliaments or the European Court of Justice should be empowered to enforce the principle of 'subsidiarity'. The heads of government of the member states should also be able to elect their own chairman, a de facto 'EU president' (a proposal reiterated 
in 2002 in joint British-French and French-German contributions). Majority voting in the Council of Ministers should be extended. The size of the Commission should be limited and Commissioners should be answerable to the European Parliament. The latter should work more closely with national parliaments and be given greater influence over law enforcement.

In May 2002 the European Commission's President Romano Prodi submitted a proposal to the convention resuming many points he had made already in 200I. The proposal sought a two-speed EU, by which euro-zone countries would be able to make decisions on their own, possibly including legislation. Finally, he suggested that the European Commission be divided into two levels, with Commissioners responsible for more central EU areas forming the inner core. It was clear that the Commission by this time saw itself as the main proponent of true, supranational integration and also as the champion of smaller EU member states, whose interests risked being ignored in a more intergovernmental EU, where bigger countries could combine on important issues to establish qualified majorities in the Council of Ministers.

Finally, the European Parliament in May 2002 presented a report to the convention proposing that the EU be given a federal constitution with a clear separation of powers among the institutions as well as between the EU and the member states. Important policy areas, such as the functioning of the Internal Market, should be the sole domain of the EU, while the say over agricultural and fisheries policies should be shared with member states. The European Parliament and the Council of Ministers should be truly equal in the legislative field.

28 In Philadelphia in 1787 the task was to take over the government of a new country, the United States of America, from its former colonial master, Great Britain, and to shape it according to the people's will. In Bonn in I948 it was about establishing a form of government that could take over from a military occupation that encouraged the undertaking, and to transform the unitary state that had existed under the Third Reich into a federal system. In Brussels in 2002 it was essentially to move democratic powers that already existed at national level to a higher level, that of the EU. Similarities with I 787 included the issue of federation, where, for example, the Federalist Papers inspired by Hamilton and Madison showed a strong federalist inclination. The issue could not, however, be pressed, due above all to the divisive question of slavery. Not until seventy years later, after the Civil War, could federalism take real hold, in the sense that Washington was given authority over the states in certain domains. Even today, however, the issue of 'states' rights' crop up occasionally (in their non-racial segregation context) in the decisions of the US Supreme Court. EU 'subsidiarity' might solve the dilemma more quickly and painlessly than was the case in the US.

29 Haider had, among other things, praised Hitler's labour policies, called Nazi concentration camps 'punishment camps' and had seemed to want to exonerate Austrian former members of the Waffen-SS of any war crimes. 
30 Austria did not go through the same Vergangenheitsbewältigung, or 'reconciliation with its past', as Germany had done after the Hitler era and World War II, when Austria had been part of the Third Reich. The country had been fortunate in obtaining the I955 State Treaty, which restored its pre-I938 borders, freed it from Soviet occupation and granted it neutrality. The controversial Wehrmacht past in the Balkans of Kurt Waldheim, Secretary General of the United Nations between I972 and I98I and Austrian President from I 986 to I992, had brought major embarrassment to the country but had not led to any truly cleansing public debate about its share in the war guilt.

3 I The decision by the fourteen EU countries to 'isolate' Austria cannot be considered an act by the EU itself, since such action would have to be taken by all the fifteen jointly. However, it was the EU presidency, Portugal, that announced the decision on behalf of the fourteen. Furthermore, the European Commission followed up with a warning to Austria, invoking the possibility of sanctions mentioned in Article 7 of the Treaty on European Union. These actions lent the decision an EU character that could be considered as going against the spirit and perhaps even the letter of EU legislation. At a minimum, the decision violated - was indeed meant to preach against - the comitas gentium (international courtesy).

32 The 'three wise men' were Marti Ahtisaari, former President of Finland; Marcellino Oreja, former Foreign Minister of Spain, former Secretary General of the Council of Europe and former European Commissioner; and Jochem Frowein, a German lawyer and Director of the German Max Planck Institute.

33 There was no similar action by the EU against Italy after its parliamentary elections in the spring of $200 \mathrm{I}$, even though its government included representatives of a far-Right party.

34 Improved Greek-Turkish relations were vital to both countries, and to Europe. They could lead to an agreement to end the division of Cyprus, a mutually accepted delineation of territorial waters and air space in the Aegean, an earlier Turkish entry into the EU and greater Turkish alignment with EU policies in the region.

35 With the weighted voting system in the EU's Council of Ministers decided at the EU's 2000 Nice Summit, Turkey, with its close to 70 million people, would have a say equal to that of any of the biggest EU countries. Since many of its regions are poor in comparison with the EU average, a considerable reorientation of EU agricultural and regional would be the likely result.

36 Already at this time the EU gave major assistance to the candidate countries. In $200 \mathrm{I}$ alone over $€_{\mathrm{I}}$ billion were awarded under the so-called Phare Programme.

37 A Facilitated Travel Document (a multi-entry and exit permit) would be available to Russian citizens for travel between the 'exclave' and Russia proper across Lithuanian territory, in future perhaps via a fast rail network. The EU would also assist Kaliningrad economically.

38 The Common Agricultural Policy also today ensures farmers the right to sell 
much of what they produce at guaranteed prices to governmental purchasing agencies. Import levies, whose level varies according to world prices, protect against foreign competition, while subsidies enable exporters to sell at prices at or below those in world markets. Following various CAP reforms, the market regulating payments as a proportion of total CAP expenditures have been reduced considerably, with direct payments to farmers (independent of production) taking their place. Around so per cent of total CAP expenditure is devoted to countryside development in its widest sense.

39 The subsidised exports of EU surpluses to developing countries, now reduced, undercut local production in these countries and drove millions to slums in the cities. This contributed to a new imbalance between countryside and city in the world's poorer countries, rendering the countryside less and less able to compete with food imports from Europe and elsewhere, and turning cities into a source of cheap labour for industries that increasingly began to compete with those in developed countries. The loss of industrial employment in, for example, Western Europe through migration of multinational companies' production units to poorer countries may therefore in part be traced back to subsidised European food exports. Big EU farmers have been the big winners under the CAP, while the small farmers (whose numbers went up as poorer and more agriculturally oriented countries joined) also had to be supported, at least enough to be able to make a living. (This they increasingly have had to learn how to do, as there are fewer jobs to be had in the rest of the economy.)

40 In October 2002 the EU agreed to increase direct payment to farmers in ten new member states gradually from 2004, so that they would reach the overall EU level by $20 \mathrm{I}_{3}$ ('phasing-in'). Total EU CAP expenditure would stay at the 2006 level during the $2007-\mathrm{I} 3$ period, at around $€_{45}$ billion per year, with annual increases of I per cent permitted.

4I Kapteyn (I996, pp. 96-7) summed up the agricultural fraud problem as follows: 'Seen from a national state perspective, one would expect [the payment of subsidies and the decision to pay] to be more or less managed by a single authority, but this was not how the Community agricultural policy worked. Member states provided the Community with its 'own resources' ... The subsidies were paid from these resources. The actual decision to pay, however, together with the procedure for checking the legitimacy of claims, became the province of national states; by comparison, the authority of the Community's control instrument, the Commission, was slight. It was given the task of comparing national decisions with procedural law and transferring money from Brussels to a member state on this basis ... In the absence of a central authority, the member states' agricultural production and the subsidies on this production spiralled upward, while their national monitoring procedures spiralled downward.'

42 The European Social Charter of the Council of Europe (an organisation separate from the European Union), adopted in I961 and revised in 1996, 
provided the first impetus to a 'social dimension' to the Internal Market. EU summits from I988 to I990 prepared the ground further. The European Commission drew up its own version of a 'social charter' in time for the December I 990 summit, but because the UK did not agree, the text could not become EU legislation but only a set of political intentions. The Maastricht Treaty left the situation unchanged for the same reason, and the agreement was simply appended to it as a 'Protocol and Agreement on Social Policy' (commonly known as the 'Social Protocol'), with a UK derogation attached to it. It was only with the I 997 agreement by the new Labour government in the UK that incorporation into EU legislation could take place. Finally, many social rights were included in the Charter of Fundamental Rights declared at the 2000 EU summit in Nice, even though the charter did not have treaty value.

43 Indeed, any authority has a natural tendency to want to do something rather than nothing, as it would otherwise call its existence into question. And that something will normally be to control something else, rather than to leave it uncontrolled.

44 The banana dispute soon took on an international dimension. It pitted the United States (acting largely on behalf of the US food multinationals Chiquita and Dole Foods) and a number of central American banana-producing countries against the EU (including the European Fyffes company) and many former European colonies covered by the EU's preferential agreement with the over seventy so-called ACP (African, Caribbean and Pacific) countries. The latter, perhaps because of the preferential access they enjoyed to EU markets for their bananas, sold at a higher price than the non-ACP countries, which offered so-called 'dollar bananas' at lower prices but found themselves largely shut out of the EU area. The Commission argued that the EU had special obligations born out of history towards ACP countries, and that the higher prices meant better salaries for plantation workers.

However, the countries shut out, as well as the US, complained that this was contrary to WTO rules, and that the ACP countries concerned had developed an unsound and excessive concentration on bananas as opposed to other types of food production. A World Bank study estimated that EU consumers paid up towards $€_{3} .5$ billion a year more than they would otherwise have done, and that only a little over $€_{I \circ O}$ million actually benefited the ACP countries themselves. The WTO's verdicts at different stages of appeal, including the final one in early I999, went against the EU.

Only in 200 I could the seven-year-old banana conflict be resolved. The EU agreed to abandon, by 2006 , essential parts of its protection of imports from ACP countries and let more bananas in from non-ACP countries, especially from Latin America. The US for its part would lift its countermeasure tariffs on a series of EU exports.

45 The EU could learn from the Icelanders. Here, one country is in charge. Flexible limits - about 25 per cent of the fishable stock per year - are 
established jointly by scientists, government and industry. The limits are raised or lowered based on constant sampling of stocks, coupled with brief periods of total bans during spawning periods or to allow young stock to mature in spawning zones. Stocks are growing steadily, adding to the country's wealth.

In 2002 the European Commission put forward a controversial proposal to restore seriously depleted fish stocks by radically cutting the size of the fishing fleet, establishing multi-year instead of annual fish quotas, tightening control over catches and protecting young fish. The proposal met with heavy opposition from especially Spain (the main beneficiary of the existing system) and also from France, Italy, Greece and Portugal. A compromise agreement reached in December 2002 was generally considered insufficient to protect threatened fish stocks.

46 The Commission in 1993 published a White Paper on growth, competitiveness and employment, calling for the halving of unemployment by the year 2000. In I994 it presented a White Paper on European social policy, with new jobs and investment as its main themes. Employment considerations were prominent in the recurrent discussions about trans-European networks. An EU summit in Essen in Germany in 1994 agreed on a European strategy against unemployment, recommending, among other things, lower extrasalary costs for employers, greater flexibility in labour markets, and unemployment and other social benefits that would not discourage people from seeking employment. The Commission in I 996 presented an update of the White Paper called 'Confidence Pact for Employment in Europe'. The Amsterdam Treaty of I 997 contained an article providing for yearly reports on the unemployment situation in the EU, with guidelines - even for individual countries - to be decided for the upcoming period by a qualified majority in the Council of Ministers. Following a commitment made in Cardiff, Wales, in I997, an EU summit in Luxembourg in November I 997 was entirely devoted to the unemployment problem. It decided to co-ordinate the struggle against joblessness by issuing common guidelines. However, no quantitative targets were given, and little in the way of new funds. The Cardiff and Luxembourg 'processes' flowed into the 'Cologne process' in June I 999 and led to a 'Jobs Pact', which was relatively short on specifics. In March 2000 a special summit on unemployment in Lisbon - rapidly termed the 'dot.com summit' - committed the EU to a major structural reform effort, including in telecommunications and financial services. By 2003, the Commission complained that little had been done to realise the Lisbon commitments and that the aim of having two-thirds of the EU workforce in employment by 2005 was at risk.

47 However, about I.5 million American men were in jail in 200I, and about eight million more were on parole, together representing nearly ro per cent of the male workforce. If one were to include these numbers, adjusted for parolees with jobs, US unemployment would rise considerably). 
48 What is logical from the 'micro' viewpoint of the individual company, namely the reduction in the number of employees to bring down costs, may clash with the logic of society as a whole. To the extent that those shed from the workforce cannot find new employment, society will have to pay them unemployment benefits. These must be financed by higher taxes on companies, people (income taxes) or sales taxes (for consumers). Companies may then find that they have to lower their prices even further to find buyers, dismiss even more workers, etc. This could lead to a vicious circle of deeper and deeper recessions and the emergence of a world economy of 'glut' - long prophesied by especially Marxist thinkers - where there would be too many things and not enough people with the money to buy them. Eventually, however, increased profits by 'downsized' companies may well be such as to permit overall economic growth, and hence employment, to resume. Some maintain this is what happened in the United States and is happening in many European countries today. 